\title{
System of Family Budgeting as a Methodological Basis for Personal Accounting and Guarantee for Growth of Financial Literacy of the Russians
}

\author{
N.V. Gorshkova \\ Doctor of Science, Professor of the chair "Theory of finances, credit, and taxation", Volgograd State University
} Email: nataly1104@yandex.ru

\author{
L.A. Mytareva \\ Ph.D., Docent of the chair "Theory of finances, credit, and taxation", Volgograd State University \\ Email: mitleyla@yandex.ru
}

\section{L.V. Perekrestova}

Doctor of Science in Economics, Professor of the chair "Theory of finances, credit, and taxation", Volgograd State University Email: perekrest.Iv@gmail.com

\begin{abstract}
A.V. Glushchenko
Doctor of Science in Economics, Professor of the chair "Accounting, analysis, and audit», Volgograd State University Email: audit@volsu.ru

O.V. Fisher

Ph.D., Docent of the chair "Theory of finances, credit, and taxation", Volgograd State University Email: olgafisher@yandex.ru
\end{abstract}

Doi:10.5901/mjss.2015.v6n5p413

\section{Abstract}

Under modern conditions of increased demand for the level of financial literacy of the economic subjects, together with an urgent problem of reduction of the level of real disposable income of the citizens, and against the background of the long financial and economic crisis, the actuality of effective management of private finances at the level of a family is very high. The authors offer an operational hypothesis stating that flexible managerial solutions in the sphere of private finances are possible on the basis of relevant information about the facts of economic life of a family, accumulated in the system of family budgeting, as a methodological basis for personal accounting. The purpose of the article is to define the terminological apparatus of scientific categories and thus develop a system of budgeting as a methodological basis for personal accounting and guarantee of the growth of financial literacy of the Russians. The tasks were the following: determining the content and specifics of the use of accounting in the sphere of private finances; defining the terminological apparatus of management of private finances; developing and offering a system of family budgets, adapted for specifics of private financial planning; testing the offered system by the example of a specific family. The research was built on the use of the methods of analysis and synthesis, induction and deduction. The research was conducted at micro- and nano-economic levels. The received results, conclusions, and offers were transformed into graphic form. The article makes a conclusion that personal accounting of a family can be viewed as a sub-type of managerial accounting and, consequently, it is possible to use the tested instrumentarium of managerial accounting in methodological development for personal family accounting. That's why the authors developed and described the system of budgets which includes the budget of incomes, expenses, and investment \& saving budget, which allows conducting the current and strategic management of personal family finances. Theoretical and methodological developments of personal accounting are shown in the article by a specific example.

Keywords: personal accounting, private finances, managing private finances, private budget, system of family budgeting.

\section{Introduction}

Under the conditions of complicating financial relations among the population, state's withdrawal from the policy of 
paternalism in the sphere of mandatory pension insurance, and quick development of the credit market against the background of high inflation rates, a special attention is paid to financial literacy of the Russians.

The Conception of long-term socio-economic development of the Russian Federation until 2020 (Concerning the Conception of long-term socio-economic development of the RF until 2020: 2008) pays special attention to financial literacy of the Russians - as it is one of the main directions of forming the investment resources.

Financial literacy is traditionally viewed as a subject's capability to manage his finances and take effective financial decisions - both in long-term and short-term (Zelentsova A.V., Demidov D.N., Bliskavka E.A.: 2012). According to the UK Financial Services Authority - FSA (a quasi-judicial body in Great Britain, responsible for regulation in the sphere of financial services, existing in Britain in 2001 - 2013), the financially literate populations conducts the account of incomes and expenses of a family; it lives within income - without unnecessary loans; financially plans in long-term; purchases financial products and services on the basis of a choice; has the knowledge of financial sphere.

Under these conditions, a special role belongs to the development of convenient and flexible instrumentarium of families' accounting of their incomes, expenses, property, and obligations, which requires the development and implementation into the Russian practice of a new sub-type of accounting, adapted to the peculiarities of private finances of the Russians - personal accounting. At present, the scientific approach to personal accounting is not yet formed in the Russian economic science. This can be explained by optionality of accounting for families, which, on the one hand, conforms to the principle of the state's not regulating the private finances in the market economy, and, on the other hand, significantly complicates implementing the methods of private financial planning into private practice, as it is based on the data of accounting and analysis: incomes and expenses of family budget, as well as volumes and structure of assets and liabilities of a family.

\subsection{Research methods}

The research is based on the methods of analysis and synthesis. The main research methods are the methods of budgeting of financial flows and resources and methods of accounting of organizations, adapted to specifics of finances of population, including economic \& mathematical and abstract \& logical.

\subsubsection{Analysis result: terminological apparatus and family budgeting system}

Managing private finances means the process of conscious task-oriented management of financial relations of individual and/or family from the position of their optimization for the purpose of achievement of the goals, set by family members (Mytareva L.A. : 2013). Life goals of individual or family are determined subjectively and are, as a matter of fact, conscious dreams and life landmarks; they are aimed at satisfaction of private needs of individual or family member and family on the whole. There purposes are peculiar landmarks and criteria of family well-being. Every life goal has two characteristics: value and time for its achievement.

The Russian authors' approaches to the system of private finances accounting are founded on the basic rules of organization's accounting (Mytareva L.A. : 2011). We support this position, but deem it advisable to determine the place of personal accounting in the existing differentiation of modern accounting (Gorshkova N.V. : 2012) in order to determine the specific accounting instrumentarium, fit for its organization. For this purpose, we shall conduct the comparative analysis of traditional sub-types of accounting: financial and managerial.

Some Russian scientists, in particular V. Titov (Titov V.: 2006), are inclined to use the principles and methods of business financial accounting for commercial organizations in the building of the system of personal accounting. In our opinion, this approach possesses several substantial drawbacks:

1. Necessity for recording every operation, which requires the user's having knowledge and skills for general accounting and personal accounting in particular of a rather high level and a lot of time. A simple event, like spending part of the advance for food, requires recording four entries: 1) accounting of income operation of receiving the advance; 2) accounting of withdrawal for buying food products; 3 ) accounting of income which is left in private assets of the household; 4) nullification of account "food" - as it is eaten. These operations are reflected in the family balance (Titov V.: 2006).

2. Obligation of the use of accrual methods, as a basic principle for business financial accounting, cannot be applied for accounting for incomes and expenses of a family, for it is impossible to spend more assets than there are - even in view of using various credit resources, offered in the market of individuals crediting. Moreover, using accrual method leads to formation of accounting income, which is a specific calculated rate that doesn't easily correlates with the volume of available money. 
In the process of the research, we formed an opinion that per totality of classification features, the personal business accounting can be attributed to the type of managerial accounting; it is possible to define it the following way. Personal accounting is an ordered system of collecting, registering, and generalizing information about the facts of economic life of a family for the purpose of effective management of private finances. At that, in our opinion, personal accounting possesses the following specific features:

- it is confidential, upon the optional basis, without legal regulation;

- possesses unigraphic form due to registration and generalization of data in account ledgers;

- income and expenses are accounted on the cash basis;

- can be performed continuously and periodically;

- includes the calculation of absolute and relative indicators which allow accumulating not only the current accounting information but forecasting it for the future;

- accountable items are incomes, expenses, property, and obligations of a family.

Supporting the thought that personal accounting can be used with practical instrumentarium of managerial accounting, we think that the methodology of tis conduct can be based on the system of budgeting which includes at least three types of yearly and monthly basic budgets: 1) income budget; 2) budget of consumer expenses (consumer budget); 3) budget of savings and investments (investment-saving budget) (Fig. 1). The system of basic budgets can be supplemented by the budget of family obligations and strategic budgets (for example, budgets of pension strategy, insurance strategy, etc.).

Property and obligations of individual and/or family are forms as a result of their participation in creation and use of private and family assets - budgets. If an individual lives in a family, he independently determines the level of his participation in the general budget formation (Gluhov V.V. : 2007). Viewing the family budget, it is advisable to dwell on a system of budgets within a single family budget, as each of its members can conduct individual accounting of his incomes and expenses (Gluhov V.V. : 2007). Correspondingly, the offered system of budgets can be duplicated on the general family and individual (personal) levels and be conducted (formed) independently by the chosen member of a family and/or jointly, and/or independently by each family member.

Unlike an organization, in which the function of chief accountant is performed by special appointed and authorized official body, the question, who is to conduct personal accounting, at the level of the family depends on the model or type of managing financial relations which is used in the family. It is possible to suppose that it will be the person that has the most managerial rights for the family budget.

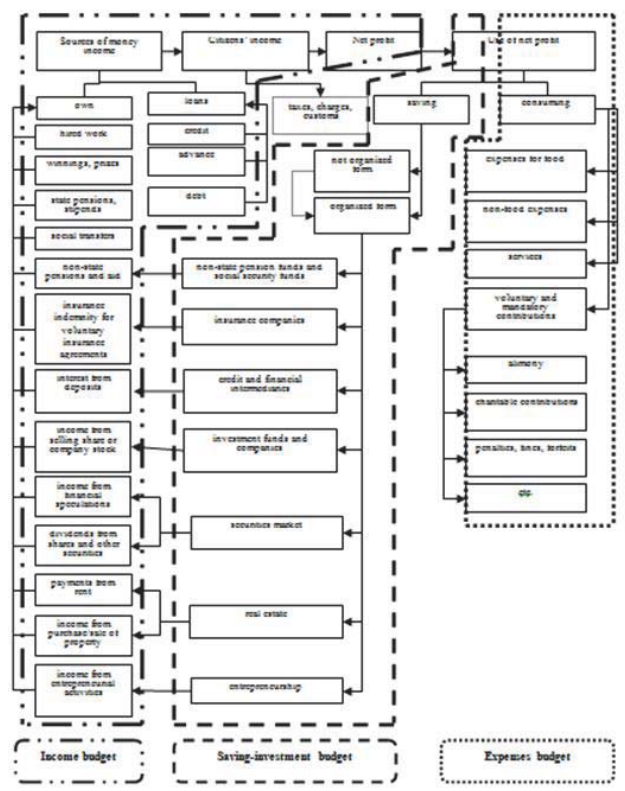

Figure 1 - Private finances and family budgets system 
Theoretically, time coverage of budgeting system can be different - daily, monthly, yearly, or even for the whole life of a person or family; though, in practice, monthly and yearly budgets are the most optimal. Continuity of personal accounting is determined by frequency of events: receiving income, outgoing expenses, saving, and purchasing saving-investment instruments. Inventory of assets and obligations should be conducted regularly, but at least once a month and at the beginning and end of every year.

Tasks of personal accounting emerge from the necessity and needs of family members for (Mytareva L.A. : 2013):

- recording and correlating the source of income and use of money assets of family and its members - as to the sums and time periods;

- optimization of correlation of family incomes with its expenses for satisfaction of needs of its members separately and in totality (private and family needs), in view of the rule of rapid development of person's needs over the possibilities for their satisfaction (i.e., family expenses always grow faster than its incomes);

- appropriation of funds from family budget for non-consumer expenses - savings and investments, as well as for business (private entrepreneurship);

- possibilities for variative management of credit obligations of a family and its separate members, of their assets and liabilities (insurance, investment, pension, and other portfolios);

- creating financial safety cushion for a family and its separate members.

On the basis of stated goals, the income and expenses budgets should be parallel, continuous, comparative, and interdependent, while recording all current incomes and expenses. Taking into account the possible gap in time and in volumes of incomes and expenses, it is necessary to save money (reserves) for closing these gaps. The necessity for formation of these reserves is determined by negative net balance between received income and planned expenses for a certain time period. Budget of savings and investments can be formed once a month. The results of monthly budgets of incomes, savings, and investments should be combined into yearly budget every year. The data of yearly budgets is necessary for building private financial plan of a family (Mytareva L.A. : 2011).

Income budget accumulates data of the account of sources, volume, and structure as to types and dynamics of family income for a certain time period (day, month, year, life). It is necessary to regularly and continuously plan, account, and evaluate (monitor) all incomes of family in absolute aspect (in the currency in which income is spent) and relative aspect (in \% from basic indicator) as to the volume, structure (sources), and dynamics.

Family members independently determine the income items, within which the accounting will be performed - on the basis of classification of incomes, their specific sources and recipients, and according to the type of managing the financial relations within this family. The incomes are accounted for in the family budget according to the contribution of each member into the common budget. The incomes which are not included into the family budget are accounted for by disposer (recipient of these incomes) independently within his private budget of incomes. The sense of income budget is not changed by this, as only its content and coverage of private incomes of each member of the family varies. When building income budget (both family and private), it is advisable to classify money incomes into active (income from labor activity of recipient - wages, bonuses, entrepreneurial income, other income from self-employment) and passive (income which are gained not from labor activity of recipient - interest from deposits, dividends, received loans, pensions, stipends, aid, income from demise, etc.). It is advisable to keep family income budget in view of all income recipients in the family, which will allow evaluating the contribution of each family member into formation of family incomes and determining the chief breadwinner and real dependents. Private income budgets suppose initially that all incomes of specific family member are taken into account in an individualized manner.

The system of keeping income budget should provide the users with relevant data as to volumes and types of incomes of family and/or its specific member, their dates and frequencies. This data are necessary for the balance of family and private expenses and incomes as to dates, volumes, and recipients.

Expenses of the family and its particular members, on the one hand, can be viewed as directions for use of their money assets - from this position, expenses are divided into consumer (expenses for consumer purposes, called "consuming") and non-consumer - saving and investments. During saving, the moment of paying for product, work, and service does not coincide in time with the moment of their consuming and/or purchase. Thus, credit is a specific form of saving (credit is a form of contract saving). Expenses of the family and its particular members is reduction of the volume of their money resources due to withdrawal of cash and non-cash (material and non-material) resources from the family, including in the form of various costs, measured during a certain time period (day, week, month, year, life).

Accordingly, consumer budget (budget of consumer expenses) generalizes the data as to directions of use of money incomes of the family and its particular members - consumer expenses, their volume, structure, dynamics, and time of performance for a certain period of time (day, month, year, life). Expenses budget can accumulate family 
expenses (family budget of expenses) and/or personal expenses of particular member of the family (private budget of expenses).

Account of expenses should record the date of expenses, volume (sum), structure, person performing expenses and/or family member, to the favor of which expenses were performed. Structure of expenses should take into account also the division of expenses into obligatory, conditionally obligatory, and optional. This division of expenses is rather subjective for each family, and the main criterion is - can a family and its particular members refuse in a one-way fashion from this type of expenses at all (optional expenses), partially reduce or change expenses (conditionally obligatory), or is it impossible without negative consequences for a family (obligatory expenses). Obligatory expenses also cover the expenses which are to be carried out by family members due to the law (taxes, fees, utility charges, etc.), contract or other signed agreement (credit contract, insurance contract, agreement for non-state pension provision, etc.) or due to court decision (alimony, compensatory damages, compensations, etc.). The volume of these expenses cannot be easily reduced in one-way fashion by family members, but it does not mean that they cannot be minimized or optimized. Conditionally obligatory and optional expenses often can be managed by family members.

Potentially, expenses of family and its particular members can be evaluated by two methods: methods of purchase (expenses include all money expenditures for purchased (consumed) products, works, and services, independent of the fullness of payment, i.e., this approach supposes that the cost of a credit car is included into family expenses for the current period) and payment method (expenses include all money expenses for fully paid products, works, and services, independent of the real moment of their purchase (consuming). For the purposes of personal accounting, it is possible to use the method of payment as a basic method, as it corresponds to the cash method of accounting, and method of purchase should be used as an additional one for the further evaluation of loan debt of the family.

Expenses of the family and its particular members should be regularly and continuously planned, accounted (monitored), and evaluated, recording them in absolute and relative aspects (in \% of basic indicator) as to volume, structure (directions and items), and dynamics. The system of accounting of consumer budgets of a family is aimed at rationalization of expenses and their balance with incomes as to time, volume, and structure. All expenses should be planned, reasoned (from the position of necessity, utility, urgency, profit and costs, and price), desirable (as to time, volume, direction), recorded and evaluated in the perspective (for the future) and retrospectively (analyzing previous expenses).

Investment and saving budget reflects the accounting of all types and forms of savings and investments of a family - both the ones performed over a certain period of time (month, year, life) and the ones previously accumulated by the family and its particular members. At that, accounting should provide the possibility for recording the data about the time of the purchase of investment and saving instrument (asset), initial cost of the purchase, current market cost, yearly profitability or unprofitableness of the asset, owner, and contractor. Such accounting should be conducted as of each month-end, with the further summarizing into a yearly budget.

Commitment budget is created when necessary - when a family has loans and non-contract (delictual) obligations. In this case, the system of accounting, besides recording their money value, moment of emergence, contractor, and specific debtor, should be oriented at reflection and observation of the value of liability (value of loan, accompanying costs, and other).

Strategic budgets are created for accounting of the data about implementation of private pension and private insurance strategies of a family and its particular members (Mytareva L.A. : 2008).

When keeping budgets of incomes and expenses, family and its members often face the problem of optimization of accounting of incomes and expenses which should allow combining planning and accounting, and also maximally simplifying the inventory of money assets (comparing the data of accounting with real quantity of money in a family for a specific time period). In this case, the solution is to use the improves method of "four envelopes" (Mytareva L.A. : 2011), when a sum required for paying utility charges is taken from income received at the beginning of a month, and the remaining sum is divided by 4.3 , and the received sums are put into four envelopes, within which there are small envelopes with intended use - for example, for food, pocket money of each family member, etc. Each of the large enveloped of the four contains the sum of money, aimed for weekly expenses of a family and its members. The rule is that it is impossible to spend the whole sum which is in the large envelope. At that same time, all sums of expenses should be recorded in the form of a table.

\subsubsection{Approbation of the system of family budgeting: example}

Family members. Family includes 4 persons which live together and keep a common budget (all incomes are combined at then distributed between family members in the form of pocket money and family expenses). The family contains two 
spouses and two children, 21 and 14 years old.

Family income. Parents and older child work and receive earned income; besides, the family received incomes from renting a second apartment out (RUB 10,000 per month). Besides, during the viewed period, the family received material help of spouses' parents which equals RUB 20,000 for purchase of a sofa. Purchase of a sofa led to the wish to renew other furniture at home - for that purpose, a loan of RUB 70,000 was taken. This is a second active loan; reimbursement of the first loan is performed by monthly annuitant payments of RUB 3,200 . The last loan payment for the first loan was in August.

Family expenses. Apart from general expenses, the viewed family has peculiarities - monthly expenses for: gym membership for the whole family (RUB 9,000 per month), medicine for the wife (RUB 4,000 per month), and insurance contributions as to the agreement for universal life insurance for the husband (RUB 4,000 per month, or RUB 48,000 per year). The family tries to optimize its consumption, so the purchase of apparel is planned and the required sums are allocated beforehand. In August, expenses for apparel were limited to RUB 8,000. Also, the family sends RUB 2,000 to the spouses' grandmothers each month (total RUB 4,000).

Savings. The family strictly follows the principle of initial saving "first, pay yourself", the size of payments is set at the level of $10 \%$ of all money incomes of the family (the money are saved even from the sum of credit received). At the end of August, the savings equaled RUB 25,900, and the remainder of RUB 32,700 was to be spent at the beginning of September for the preparation of the younger child for the school.

Accordingly, the budgets of incomes and expenses in absolute values for the viewed family are shown in Table 1 , in relative values - in Table 2.

Table 1. Monthly system of budgets of incomes and expenses of the family, adapted to the methods of 4 envelopes (August 2014, thousand RUB)

\begin{tabular}{|c|c|c|c|c|c|c|c|c|c|}
\hline \\
\hline \multirow{2}{*}{ Incomes } & \multicolumn{2}{|c|}{$1^{\text {st }}$ week* $^{*}$} & \multicolumn{2}{|c|}{$2^{\text {nd }}$ week } & \multicolumn{2}{|c|}{$3^{\text {rd }}$ week } & \multicolumn{2}{|c|}{$4^{\text {th }}$ week } & \multirow{2}{*}{ Tota } \\
\hline & RP & $\Sigma$ & RP & $\Sigma$ & RP & $\Sigma$ & RP & $\Sigma$ & \\
\hline I. Active income & \multicolumn{2}{|c|}{88} & \multicolumn{2}{|c|}{32} & \multicolumn{2}{|c|}{24} & \multicolumn{2}{|c|}{15} & 159 \\
\hline 1.1 Earned income of the husband, including: & \multicolumn{2}{|c|}{48} & \multicolumn{2}{|c|}{32} & \multicolumn{2}{|c|}{0} & \multicolumn{2}{|c|}{0} & 80 \\
\hline - $\quad$ wages, advance & 01 & 48 & & & & & & & 48 \\
\hline - $\quad$ bonus & & & 15 & 32 & & & & & 32 \\
\hline 1.2 Earned income of the wife, including: & \multicolumn{2}{|c|}{26} & \multicolumn{2}{|c|}{0} & \multicolumn{2}{|c|}{16} & \multicolumn{2}{|c|}{15} & 57 \\
\hline - $\quad$ wages, advance & $\underline{05}$ & 26 & & $\underline{24}$ & 16 & & & 16 \\
\hline - $\quad$ cash reward and others & & & & & & & 28 & 15 & 15 \\
\hline 1.3 Earned income of the working child, including: & \multicolumn{2}{|c|}{14} & \multicolumn{2}{|c|}{0} & & & T( & & 22 \\
\hline - $\quad$ wages, advance & 04 & 14 & & & 19 & 8 & & & 22 \\
\hline II. Passive income & & & & & & & T & & 100 \\
\hline Interest on deposits & & & & & & & & & \\
\hline Dividends & & & & & & & & & \\
\hline Income from selling property & & & & & & & & & \\
\hline Received loans & & & & & 20 & 70 & & & 70 \\
\hline Return of a debt into the family & & & & & & & & & \\
\hline Gifts received by the family members & & & & & & & & & \\
\hline Received material help from relatives & $\underline{06}$ & 20 & & & & & & & 20 \\
\hline Income from renting out property & & & 11 & 10 & & & & & 10 \\
\hline Other & & & & & & & & & \\
\hline TOTAL income for the period & 1 & & & & & & 1 & & 259 \\
\hline Family expenses budget & & & & & & & & & \\
\hline Fvnenge & $1^{\text {st }} u$ & $\mathrm{ek}^{*}$ & $2^{\text {nd }}$ & eek & $3^{\text {rd }}$ & eek & $4^{\text {th }} v$ & & Total \\
\hline Expenses & $\mathrm{RP}$ & $\Sigma$ & $\mathrm{RP}$ & $\Sigma$ & RP & $\Sigma$ & RP & $\Sigma$ & \\
\hline II. Obligatory expenses & & & & & & & 5 & & 55 \\
\hline 2.1 Included into SAVINGS of the family, at least $10 \%$ of each income & 10 & & & & & & 1 & & 25.9 \\
\hline $\begin{array}{l}\text { A. Saved from money income received from labor activity of each family } \\
\text { member, including: }\end{array}$ & & & & & & & & & 15.9 \\
\hline - from earned income of the husband, including: & & & & & & & & & 8.0 \\
\hline wages, advance & $\underline{01}$ & 4.8 & & & & & & & 4.8 \\
\hline bonus & & & 15 & 3.2 & & & & & 3.2 \\
\hline - from earned income of the wife, including: & & & & & & & 1 & & 5.7 \\
\hline - $\quad$ wages, advance & $\underline{05}$ & 2.6 & & & $\underline{24}$ & 1.6 & & & 4.2 \\
\hline - $\quad$ cash reward etc. & & & & & & & 28 & 1.5 & 1.5 \\
\hline - from earned income of the working child, including: & & & & & & & 7 & & 2.2 \\
\hline
\end{tabular}




\begin{tabular}{|c|c|c|c|c|c|}
\hline wages, advance & 1.4 & & 0.8 & & 2.2 \\
\hline $\begin{array}{l}\text { B. Saved from money income which is not connected with labor activity } \\
\text { of family members, including: }\end{array}$ & 2.0 & 1.0 & 7.0 & 0 & 10.0 \\
\hline \multicolumn{6}{|l|}{ Interest on deposits } \\
\hline \multicolumn{6}{|l|}{ Dividends } \\
\hline \multicolumn{6}{|l|}{ Income from selling property } \\
\hline Received loans & & & 7.0 & & 7.0 \\
\hline \multicolumn{6}{|l|}{ Return of a debt into the family } \\
\hline \multicolumn{6}{|l|}{ Gifts received by the family members } \\
\hline Received material help from relatives & 2.0 & & & & 2.0 \\
\hline Income from renting out property & & 1.0 & & & 1.0 \\
\hline Other & & & & & 0 \\
\hline 2.2 Obligatory Payments, including: & 25.1 & 0 & 0 & 4 & 29.1 \\
\hline Utility charges (by the $10^{\text {th }}$ of each month) & 8.9 & 0 & 0 & 0 & 8.9 \\
\hline - $\quad$ maintenance, including electricity & 4.5 & & & & 4.5 \\
\hline - $\quad$ phone & 0.8 & & & & 0.8 \\
\hline gas & 0.8 & & & & 0.8 \\
\hline - $\quad$ Internet & 0.7 & & & & 0.7 \\
\hline - $\quad$ apartment security & 1.5 & & & & 1.5 \\
\hline - $\quad$ cable TV & 0.6 & & & & 0.6 \\
\hline Gym membership for all family members & $\underline{01}$ & & & & 9 \\
\hline Medicine for the husband & $\underline{\underline{01}}$ & & & & 4 \\
\hline $\begin{array}{l}\text { Insurance contributions for the agreement of universal life insurance of the } \\
\text { husband }\end{array}$ & & & & д028 & 4 \\
\hline Loan reimbursement (by the $10^{\text {th }}$ of each month) & 3.2 & & & & 3.2 \\
\hline III. Conditionally obligatory expenses & 19.7 & 17.2 & 18.2 & 17.2 & 72.3 \\
\hline Food products at home & 6 & 4 & 6 & 4 & 20 \\
\hline Everyday expenses & 1.5 & 1 & 1 & 1 & 4.5 \\
\hline Pocket money of each family member & 8.2 & 8.2 & 8.2 & 8.2 & 32.8 \\
\hline$\bullet \quad$ Husband & 2.5 & 2.5 & 2.5 & 2.5 & 10 \\
\hline - $\quad$ Wife & 2.5 & 2.5 & 2.5 & 2.5 & 10 \\
\hline - $\quad$ Working child & 2.5 & 2.5 & 2.5 & 2.5 & 10 \\
\hline - $\quad$ Second child & 0.7 & 0.7 & 0.7 & 0.7 & 2.8 \\
\hline Expenses for gifts and organization of parties, birthday parties, etc. & & & 3 & & 3 \\
\hline Support for relatives & 4 & & & & 4 \\
\hline Necessary apparel & & 4 & & 4 & 8 \\
\hline Other & & & & & 0 \\
\hline IV. Optional expenses & 3 & 2 & 90 & 0 & 75 \\
\hline Entertainment (cafe, theaters, cinema, etc.) & 3 & & & & 3 \\
\hline Family members' hobbies & & 2 & & & 2 \\
\hline Expenses for recreation & & & & & 0 \\
\hline Apparel over the necessary minimum & & & & & 0 \\
\hline Purchase of expensive goods of long-term use & & & 90 & & 70 \\
\hline Renovations & & & & & 0 \\
\hline Other & & & & & 0 \\
\hline Total expenses for the period & 58.6 & 23.4 & 117.6 & 26.7 & 226.3 \\
\hline Balance $^{\star *}$ & +49.4 & +18.6 & -23.6 & -11.7 & 32.7 \\
\hline V. Current balance of money assets (current reserve) & 49.4 & 68 & 44.4 & 32.7 & 32.7 \\
\hline Balance & & & 259 & & \\
\hline
\end{tabular}

Endnotes: RP - receipt day; $\Sigma$ - sum;

* August of 2014 contains more than 4 weeks, so the first 3 days and the next 7 days are conventionally combined into the first week;

** balance is defined as difference between incomes and expenses; positive balance shows the emergence of reserve which, if necessary,

can be taken to the loss period; negative balance shows the necessity to use the previously formed reserves (money reserves).

*** current balance of money assets (current reserve) reflects the sum of money assets which remains in the family in the form of reserve in the current period after all current expenses.

Table 2. Analytical system of monthly system of budgets of incomes and expenses of the family, adapted to the methods of 4 envelopes, August 2014

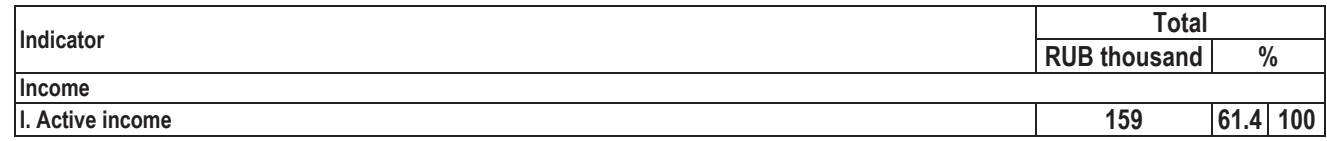




\begin{tabular}{|c|c|c|c|}
\hline 1.1 Earned income of the husband, including: & 80 & 30.9 & 50.4 \\
\hline 1.2 Earned income of the wife, including: & 57 & 22 & 35.8 \\
\hline 1.3 Earned income of working child, including: & 22 & 8.5 & 13.8 \\
\hline II. Passive income & 100 & 38.6 & 100 \\
\hline Received loans & 70 & 27 & 70 \\
\hline Received material help from relatives & 20 & 7.7 & 20 \\
\hline Income from renting out property & 10 & 3.9 & 10 \\
\hline Total income per month & 259 & 100 & \\
\hline \multicolumn{4}{|l|}{ Expenses } \\
\hline II. Obligatory expenses & 55 & 21.2 & 100 \\
\hline 2.1 Included into SAVINGS of the family, at least $10 \%$ of each income & 25.9 & 10 & 47.1 \\
\hline A. Saved from money income received from labor activity of each family member, including: & 15.9 & 6 & \\
\hline - from earned income of the husband, including: & 8.0 & 3 & \\
\hline - $\quad$ wages, advance & 4.8 & & \\
\hline bonus & 3.2 & & \\
\hline - from earned income of the wife, including: & 5.7 & 2.2 & \\
\hline wages, advance & 4.2 & & \\
\hline cash reward, etc. & 1.5 & & \\
\hline - from earned income of the working child, including: & 2.2 & 0.8 & \\
\hline • wages, advance & 2.2 & & \\
\hline B. Saved from money income which is not connected with labor activity of family members, including: & 10.0 & 3.9 & \\
\hline Received loans & 7.0 & & \\
\hline Received material help from relatives & 2.0 & & \\
\hline Income from renting out property & 1.0 & & \\
\hline Other & 0 & & \\
\hline 2.2 Obligatory Payments, including: & 29.1 & 11.2 & 52.9 \\
\hline Utility charges (by the $10^{\text {th }}$ of each month) & 8.9 & 3 & 100 \\
\hline - $\quad$ maintenance, including electricity & 4.5 & & 50.6 \\
\hline - $\quad$ phone & 0.8 & & 9 \\
\hline - gas & 0.8 & & 9 \\
\hline - $\quad$ Internet & 0.7 & & 7.8 \\
\hline - $\quad$ apartment security & 1.5 & & 16.8 \\
\hline - $\quad$ cable TV & 0.6 & & 6.8 \\
\hline Gym membership for all family members & 9 & 3.5 & \\
\hline Medicine for the husband & 4 & 1.5 & \\
\hline Insurance contributions for the agreement of universal life insurance of the husband & 4 & 1,5 & \\
\hline Loan reimbursement (by the $10^{\text {th }}$ of each month) & 3.2 & 1.2 & \\
\hline III. Conditionally obligatory expenses & 72.3 & 27.9 & 100 \\
\hline Food products at home & 20 & 7.7 & 27.7 \\
\hline Everyday expenses & 4.5 & 1.7 & 6 \\
\hline Pocket money of each family member & 32.8 & 12.7 & 45.4 \\
\hline - $\quad$ Husband & 10 & & \\
\hline - Wife & 10 & & \\
\hline - $\quad$ Working child & 10 & & \\
\hline - $\quad$ Second child & 2.8 & & \\
\hline Expenses for gifts and organization of parties, birthday parties, etc. & 3 & 1.1 & 4 \\
\hline Support for relatives & 4 & 1.5 & 5.5 \\
\hline Necessary apparel & 8 & 3 & 11 \\
\hline Other & 0 & & \\
\hline IV. Optional expenses & 75 & 28.9 & 100 \\
\hline Entertainment (cafe, theaters, cinema, etc.) & 3 & 1.1 & 4 \\
\hline Family members' hobbies & 2 & 0.7 & 2.7 \\
\hline Expenses for recreation & 0 & & \\
\hline Purchase of expensive goods of long-term use & 70 & 27 & 93.3 \\
\hline Total expenses for the period & 226.3 & 87.4 & \\
\hline Balance $^{* *}$ & 32.7 & & \\
\hline V. Current balance of money assets (current reserve) ${ }^{\star \star \star}$ & 32.7 & 12.6 & \\
\hline
\end{tabular}


As a result, the system of family budgeting can be presented as a scheme for accounting of income, expenses, property, and family liabilities (Fig. 2).



Figure 2 - Schemes of accounting of family incomes and expenses

Managing budget of incomes and expenses in absolute and relative values allows comparing the level and dynamics of yearly indicators and tracking changes of the structure of incomes and expenses, as well as allocating the average yearly structure. With more empirical data, a family can plan the optimal structure of expenses and incomes more effectively, which will allow using the current financial potential in a more efficient way, by means of building and implementing private financial plan.

The viewed structure of incomes and expenses budgets is oriented primarily at recording and stating the real financial state of the family. If necessary, it is possible to allocate the specific groups of items, in the view of which, the monitoring of incomes and expenses will be oriented at: improving financial position of the family and its members, leaving the crisis situation, and being under the regime of tough economy. The above mentioned is very important, as according to Public opinion monitoring, most Russians (66\%) live in the regime of constant saving, $13 \%$ started to save a while ago, and only $13 \%$ of the respondents do not save at all (Financial behavior of population : 2013). At that, $59 \%$ of the respondents are sure that their material position will remain the same, $12 \%$ think that it will worsen, and 22\% think that it will improve. According to the National Agency for Financial Studies (NAFS web-site : 2015), only 15\% of the Russians plan their pensions (while $53 \%$ of them plan to live on their savings retirement), despite the fact that more than $60 \%$ of the respondents think that they will lack money after retirement. On the whole, the Russians spend more than $70 \%$ of income on consumption, and only $15 \%$ of income - on savings, investments, and insurance (Ratio of preferred consumer and investment activity of population. In this situation, 37\% of the Russians can live off their savings at least 1 
month, while only $3 \%$ can live more than 1 year without additional sources of income (Subjective assessment of the population about the period during which they could only live on their savings : 2011). According to the survey by the recruiting web-site Superjob.ru conducted in 2012, around $40 \%$ of the Russians sometimes track their financial flows, and only $28 \%$ do it regularly (The Russians put off financial planning on the back burner : 2015). The rest of the citizens do not consider recording their income and expenses to be important.

About one third of the Russians, which managed their budgets, do it not for achievement of specific financial goals, but "just in case". Only the third part of citizens conducts the accounting of assets for the purpose of financial discipline. All of this influences directly the content and structure of private financial plan in the case of its building. This situation explicitly shows the necessity for constant planning of private finances of families, which is impossible without personal accounting.

The conducted research allowed concluding the following:

- possibility for the Russian families' leading effective household economy under difficult modern economic conditions is based on the wish and skill to manage private finances for achievement of strategic and tactical goals of individual/family;

- managing private family finances should include leading personal accounting which has features that, as to economic aspect, are close to managerial accounting;

- as a practical instrumentarium of personal accounting, there was created a system of budgets, allowing not only accumulating the information about previous facts of family life but also forecasting incomes, expenses, property, and liabilities of a family in future.

Information: currency exchange rate, set by the Bank of Russia for $09.05 .2015-1 \$=50.7511 \mathrm{P}, 1 €=56.8971 \mathrm{P}$.

\section{Acknowledgement}

This research was conducted with financial support from the Russian Humanitarian Scientific Fund and the Administration of Volgograd Oblast within the scientific and research project "Potential of region's population finances as an innovational factor for well-balanced regional development (by the example of Volgograd Oblast)" No. 14-12-34026 a/N.

\section{References}

Financial behavior of the population. Monitoring of public opinion: economic and social change (2013), 1, 76 - 84.

Financial Capability in the UK: Establishing a Baseline [Online] Available: http://www.fsa.gov.uk/financial_capability (April 18, 2015).

Gluhov, V.V. (2007). Collective models of financial management in the household. Journal "Digest-Finance", 6 (150), 47 - 51.

Gluhov, V.V. (2007). Specificity of Finance of households. Journal "Financial research", 14, 83-86.

Gorshkova, N.V. (2012). Historical development of the consolidated accounting and reporting in the Russian Federation Journal "International accounting", 16 (214), 2-6.

Zelentsova, A.V., Demidov, D.N., Blyskavcka, E.A. (2012). Improving financial literacy: international experience and Russian practice : Research center Payment Systems and Settlements [Online] Available: http://allbestlib.ru/publ/biznes_knigi/povyshenie finansovoj_gramotnosti_naselenija_mezhdunarodnyj_opyt_i_rossijskaja_praktika_a_v_zelencova_d_n_demidov_e_a_bliskavkal 3-1-0-3855 (April 18, 2015).

Mytareva, L.A. (2011). Personal accounting of the household: issues of theory and practice. Journal "Financial analyst. Problems and solutions", 16 (58), 58 - 62.

Mytareva, L.A. (2013). Personal finance management: notebook-workshop. Volgograd: VolSU Publ.

Mytareva, L.A. (2011). Personal financial plan of households: textbook (in the framework of the course "Finance of households"). Volgograd: Volgograd scientific publishing house.

Mytareva, L.A. (2008). Personal pension strategy of Russians: the main instruments Journal "Financial analyst. Problems and solutions", $1,77-82$.

On the concept of long-term socio-economic development of the Russian Federation for the period up to 2020: the Government of Russian Federation, dated November 17, 2008 No. 1662-R [Online] Available: http://base.garant.ru/194365/\#ixzz38McQ4qP7 (April 24, 2015).

Subjective assessment of the population about the period during which they could only live on their savings (2011). Source: ZIRCON. [Online] Available: http://www.zircon.ru/upload/iblock/d6a/MFAN-2011.pdf (April 24, 2015).

The Russians put off financial planning on the back burner. [Online] Available: http://bank.ru/publication/show/id/14209/ (April 24, 2015)

The website of NAFI. [Online] Available: http://nacfin.ru/novosti-i-analitika/press/press/single/10673.html (April 24, 2015).

Titov, V. (2006). Personal Finance at your fingertips. ICP Maska LLC. 